\title{
Compression of Color Image Using Quantization Method
}

\author{
Denni M Rajagukguk ${ }^{1}$, Iqbal Panjaitan ${ }^{2}$ \\ 1,2 Manajemen Informatika, Universitas Imelda Medan \\ Email: dennimr17@gmail.com ${ }^{1}$, iqbalpanjaitan12@gmail.com²
}

\begin{tabular}{ll}
\hline Keywords & $\begin{array}{l}\text { Abstract. The development of large-capacity storage media causes people to no longer } \\
\text { have problems if they have large files. More so if the file we have is an image file. } \\
\text { Nevertheless, sometimes the large file size feels annoying if we have to manage the } \\
\text { storage media that we have for various data, thepurpose of this study is to compress color } \\
\text { imagery. By using quantization method can be taken, By using data compression then } \\
\text { the data capacity will be minimized, Utilization of quantization method will facilitate } \\
\text { data compression (image), Image compression with kunatization method in RGB Image } \\
\text { Quantization } \\
\text { can reduce thesize of the compressed file, so as to save storage space(Storage). }\end{array}$ \\
\hline
\end{tabular}

\section{INTRODUCTION}

The development of large-capacity storage media causes people to no longer have problems if they have large files. More so if the file we have is an image file. However, sometimes the large file size feels annoying if we have to manage the storage media that we have for various data [1], [2]. Especially if the file will be sent electronically, of course the capacity of the file becomes a problem in itself. Image compression is the process of minimizing the number of bits that represent an image so that the image size becomes smaller. Basically image compression techniques are used for data transmission and storage. Image compression is widely applied to television broadcasting, remote sensing, military communication, radar and others [3].

Nowadays the use of RGB imagery (Read, Greed, Blue) is already a necessity in various fields. However, its use is constrained by large file capacity, but it is possible to compress the imagery according to your needs. RGB imagery is a 3-dimensional matrix, i.e. length dimension, width dimension and RGB dimension. If further parsed, three two-dimensional matrices will be obtained, call it $\mathrm{R}$ matrix, $\mathrm{G}$ matrix, $\mathrm{B}$ matrix. With quantization methods, the $\mathrm{R}$ matrix, $\mathrm{G}$ matrix and $\mathrm{B}$ matrix will be reduced in tier, resulting in the number of bits used to represent the image to be reduced. As the number of bits decreases, the file size becomes smaller. The quantization method belongs to the Lossy Compression category, so the compressed image cannot be decompressed again as it was because of missing information [4], [5].

To solve the problem above one of the solutions is to compress the information data so that it is smaller than the original size without reducing the content of the data. Thus, various algorithms were created regarding data compression. Data compression algorithms that are lossy and lossless have been widely known and researched. Similarly, the development with lossless compressionalgorithm, which for this type of algorithm is used for the purposes of transferring important data that requires no data loss. This has given rise to a variety of new lossless algorithms that have diverse performance and quality [6].

\section{METHOD}

\subsection{Image Data Encoding in RGB}

Data is stored in the computer on the main memory for processing. A character of data stored in the main memory occupies a position of 1 byte. On the first generation computer, 1 byte consists of 4 bits, the second generation computer, 1 byte consists of 6 bits and on the current generation computer, 1 byte consists of 8 bits. A character of data stored in main memory is represented by a combination of binary digits (binary digits or bits). A binary code can be used to represent a character[7]. A different computer uses different binary code to represent a character. A 1-byte computer consists of 4 bits, using binary code in the form of a combination of 4 bits, namely BCD (Binary Coded Decimal).

Computers that use 6 bits for 1 byte, using binary code consisting of 6 combinations of bits, Jurnal Info Sains : Informatikan dan Sains is licensed under a Creative Commons Attribution-Non Commercial 4.0 International License (CC BY-NC 4.0) 
namely SBCDIC (Standard Binary Coded Decimal Interchange Code). A computer consisting of 8 bits, using binary code consisting of a combination of 8 bits, namely EBCDIC (Extended Binary Coded Decimal Interchange Code) or ASCII (American Standard Code of Information Interchange) [2].

\subsection{Digital Imagery Basics}

Digital imagery is a two-dimensional image that can be displayed on a computer monitor screen as a diskretic set of digital values called pixels (picture elements). A pixel is an image element that has a value that indicates the intensity of color.Based on how it is storeed or built, digital imagery can be divided into two types. The first type is a digital image formed by a collection of pixels in a twodimensional array. This type of image is called a bitmap image or raster image. The second type of imagery is an image formed by geometric and mathematical functions. This type of image is calledvector graphics. Digital imagery (discrete) is produced from analog imagery (continuous) through digitization Digitalization of analog imagery consists of sampling and quantization (quantization) Desecration is the division of imagery into discrete elements (pixels), while quantization is the giving ofvalue, color intensity on each pixel with a value that is an integer. The amount of value that can be used in image quantization depends on the pixel depth, which is the number of bits used to represent the intensity of pixel color. Pixel depth is often referred to as color depth. Digital images that have a pixel $n$ bit depth are also called n-bit images. Based on the constituent colors, digital imagery can be divided into three kinds: Binary image, which is an image consisting of only two colors, black and white. Therefore, each pixel of the binary image is simply represented by 1 bit [8], [9].
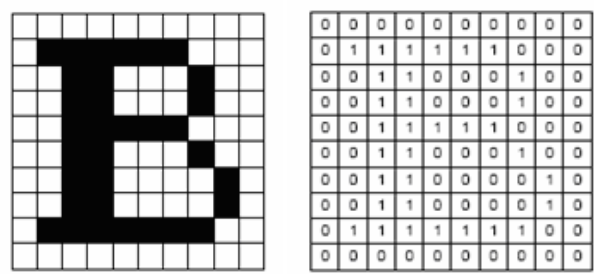

Figure 1. binary imagery and Image representation

Although color imagery is currently preferred because it gives a richer impression of binary imagery, it does not make binary images die. In some applications binary imagery is still needed, for example the image of the agency logo ( which consists only of black and white), the image of the goods code (bar code) listed on the label of the goods, the image of the scanned text document, and so on. As mentioned above, binary imagery has only two grayish degree values: black and white. Pixel - object pixel is 1 and pixel - background pixel is 0 . at the time of displaying the image, is white and 1 is black. So in binary image, the background is white while the object is black as shown in figure 2.1 above. Although computers today can process both grayscale and color imagery, binary images are still maintained [10].

\section{RESULTS AND DISCUSSION}

Quantization-based compression uses a method of reducing the amount of color intensity, thus reducing the number of bits used to represent an image. This compression is lossy, as the intensity of the color is reduced.

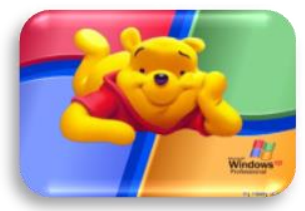

Figure 2 Image to beused

\subsection{Quantization Compression Algorithm}

Jurnal Info Sains : Informatikan dan Sains is licensed under a Creative Commons Attribution-Non Commercial 4.0 International License (CC BY-NC 4.0) 
Quantization compression algorithm is to find the size of the image matrix and look for the degree value of R,G,B image to double as follows :

Compression $=$ gblama =imread('famili.jpg');

$[\mathrm{m}, \mathrm{n}, \mathrm{o}]=\operatorname{size}($ gblama);

array=double (gblama);

gbbaru=zeros $(m, n, 3)$;

for $\mathrm{k}=1: 0$

for $\mathrm{i}=1: \mathrm{m}$

for $\mathrm{j}=1: n$

if $(\bmod (\operatorname{array}(\mathrm{i}, \mathrm{j}, \mathrm{k}), 2)==0)$

else

imagenew $(\mathrm{i}, \mathrm{j}, \mathrm{k})=(\operatorname{array}(\mathrm{i}, \mathrm{j}, \mathrm{k})+1) / 2$;

imagenew $(\mathrm{i}, \mathrm{j}, \mathrm{k})=(\operatorname{array}(\mathrm{i}, \mathrm{j}, \mathrm{k})) / 2$;

end

end

end

end

Step 1;

The steps to determine the fiqh or image as follows:

Number of image pixels $=80$

Grayish degree $=256$ (24 bits)

Then the histrogram:

Table 1 RGB Color Histogram Table

\begin{tabular}{cccc}
\hline $\begin{array}{c}\text { Degree of } \\
\text { Grayness }\end{array}$ & $\begin{array}{c}\text { Number of } \\
\text { Pixels of } \\
\text { Color R }\end{array}$ & $\begin{array}{c}\text { Number of } \\
\text { Pixels of Color } \\
\text { G }\end{array}$ & $\begin{array}{c}\text { Number of Pixels } \\
\text { Color B }\end{array}$ \\
\hline 0 & 0 & 0 & 0 \\
1 & 0 & 0 & 0 \\
2 & 0 & 0 & 0 \\
3 & 0 & 0 & 0 \\
4 & 0 & 0 & 1 \\
5 & 0 & 0 & 0 \\
6 & 0 & 0 & 1 \\
7 & 0 & 0 & 0 \\
8 & 0 & 0 & 0 \\
9 & 0 & 0 & 2 \\
10 & 0 & 0 & 2 \\
11 & 0 & 0 & 0 \\
12 & 0 & 0 & 1 \\
13 & 0 & 0 & 0 \\
14 & 0 & 0 & 0 \\
15 & 0 & 0 & 4 \\
254 & 0 & 0 & \\
255 & 0 & 0 & \\
\hline
\end{tabular}

Step 2 :

For example, it will be compressed from 256 to 128 degrees grayish (7 bits) i.e. grayish value 0 to 127 , then made $\mathrm{n}$ group fruit that is 128 . Each group has an average of $80 / 7=11.42$ pixels (can be less)

Table 2 New Grayish Value Grouping

Jurnal Info Sains : Informatikan dan Sains is licensed under a Creative Commons Attribution-Non Commercial 4.0 International License (CC BY-NC 4.0) 


\begin{tabular}{|c|c|c|c|c|c|c|c|}
\hline $\mathrm{K}$ & Gray & Pixel R & Pixel G & Pixel B & $\mathrm{P}-\mathrm{KR}$ & PK-G & PK-B \\
\hline \multirow[t]{2}{*}{1} & 0 & 0 & 0 & 2 & & & \\
\hline & 1 & 0 & 0 & 0 & 0 & 0 & 2 \\
\hline \multirow[t]{2}{*}{2} & 2 & 0 & 0 & 0 & & & \\
\hline & 3 & 0 & 0 & 0 & 0 & 0 & 0 \\
\hline \multirow[t]{2}{*}{3} & 4 & 0 & 0 & 1 & & & \\
\hline & 5 & 0 & 0 & 0 & 0 & 0 & 1 \\
\hline \multirow[t]{2}{*}{4} & 6 & 0 & 0 & 1 & & & \\
\hline & 7 & 0 & 0 & 0 & 0 & 0 & 1 \\
\hline \multirow[t]{2}{*}{5} & 8 & 0 & 0 & 0 & & & \\
\hline & 9 & 0 & 0 & 2 & 0 & 0 & 2 \\
\hline \multirow[t]{2}{*}{6} & 10 & 0 & 0 & 2 & & & \\
\hline & 11 & 0 & 0 & 0 & 0 & 0 & 2 \\
\hline \multirow[t]{2}{*}{7} & 12 & 0 & 0 & 0 & & & \\
\hline & 13 & 0 & 0 & 1 & 0 & 0 & 1 \\
\hline \multirow[t]{2}{*}{8} & 14 & 0 & 0 & 0 & & & \\
\hline & 15 & 0 & 0 & 0 & 0 & 0 & 0 \\
\hline \multirow[t]{2}{*}{9} & 16 & 0 & 0 & 1 & & & \\
\hline & 17 & 0 & 0 & 0 & 0 & 0 & 1 \\
\hline \multirow[t]{2}{*}{10} & 18 & 0 & 0 & 0 & & & \\
\hline & 19 & 0 & 0 & 0 & 0 & 0 & 0 \\
\hline \multirow[t]{2}{*}{11} & 20 & 0 & 0 & 0 & & & \\
\hline & 21 & 0 & 0 & 0 & 0 & 0 & 0 \\
\hline
\end{tabular}

Step 3 :

Each pixel or image in the group is encoded with a new gray value of 0 to 127

Table 3 New Coding Group Table

\begin{tabular}{ccc}
\hline group & Old Gray Value & New Gray Value \\
\hline 1 & 0 & 0 \\
& 1 & \\
2 & 2 & 1 \\
3 & 3 & \\
& 4 & 2 \\
4 & 5 & 3 \\
5 & 6 & \\
& 7 & 4 \\
\hline
\end{tabular}

Jurnal Info Sains : Informatikan dan Sains is licensed under a Creative Commons Attribution-Non Commercial 4.0 International License (CC BY-NC 4.0) 


\begin{tabular}{lll}
\hline 6 & 9 & \\
& 10 & 5 \\
7 & 11 & \\
& 12 & 6 \\
8 & 13 & \\
& 14 & 7 \\
9 & 15 & \\
& 16 & \\
10 & 17 & 9 \\
& 18 & \\
11 & 19 & 10 \\
& 20 & \\
12 & 21 & 11 \\
\end{tabular}

Image that has been compressed with the following matrix:

Matrices R:

$\begin{array}{llllllllll}100 & 119 & 123 & 120 & 35 & 61 & 27 & 53 & 106 & 40 \\ 35 & 107 & 125 & 111 & 110 & 97 & 67 & 48 & 65 & 113 \\ 108 & 113 & 111 & 125 & 90 & 58 & 89 & 123 & 100 & 94 \\ 94 & 96 & 107 & 99 & 77 & 97 & 92 & 46 & 94 & 109 \\ 115 & 63 & 60 & 54 & 31 & 42 & 112 & 125 & 117 & 64 \\ 60 & 53 & 24 & 66 & 117 & 125 & 124 & 124 & 124 & 124 \\ 124 & 124 & 124 & 124 & 124 & 124 & 124 & 124 & 124 & 124\end{array}$

Matrices G:

$\begin{array}{llllllllll}3 & 42 & 58 & 48 & 39 & 26 & 56 & 86 & 22 & 39 \\ 91 & 85 & 77 & 84 & 84 & 88 & 28 & 39 & 83 & 99 \\ 81 & 70 & 94 & 97 & 69 & 78 & 50 & 30 & 78 & 74 \\ 88 & 100 & 72 & 87 & 73 & 28 & 33 & 40 & 36 & 89 \\ 75 & 78 & 83 & 76 & 46 & 60 & 75 & 77 & 76 & 67 \\ 50 & 47 & 69 & 88 & 86 & 77 & 74 & 66 & 45 & 52 \\ 71 & 89 & 92 & 92 & 92 & 92 & 92 & 92 & 92 & 92 \\ 92 & 92 & 92 & 92 & 92 & 92 & 92 & & & \end{array}$

Matrices B:

$\begin{array}{llllllllll}36 & 53 & 62 & 56 & 0 & 69 & 69 & 50 & 38 & 53 \\ 31 & 31 & 12 & 26 & 39 & 58 & 83 & 93 & 13 & 5 \\ 4 & 2 & 19 & 55 & 127 & 117 & 25 & 16 & 3 & 6 \\ 0 & 39 & 127 & 72 & 4 & 12 & 8 & 6 & 5 & 16 \\ 127 & 93 & 46 & 39 & 64 & 23 & 22 & 31 & 127 & 127 \\ 126 & 126 & 77 & 18 & 37 & 43 & 127 & 126 & 125 & 118 \\ 53 & 18 & 36 & 44 & 44 & 44 & 44 & 44 & 44 & 44 \\ 44 & 44 & 44 & 44 & 44 & 44 & 44 & & & \end{array}$

Jurnal Info Sains : Informatikan dan Sains is licensed under a Creative Commons Attribution-Non Commercial 4.0 International License (CC BY-NC 4.0) 
Compression ratio $=100 \%-\left(\frac{128}{256} \times 100 \%\right)=\mathbf{5 0 \%}$, means that the original image has been compressed as much as $\mathbf{5 0 \%}$.

\section{CONCLUSION}

By using quantization method can be taken, By using data compression then the data capacity will be minimized, Utilization of quantization method will facilitate data compression (image), Image compression with kunatization method in RGB Image can reduce thesize of the compressed file, so as to save storage space (Storage).

\section{REFERENCE}

[1] G.D.Sanjaya, R.Hadi, N.Luh, and G.Pivin, "Kompresi Citra Digital Menggunakan Metode Discrete Cosine Transform," 2018.

[2] M. A. Maricar and O. Widyantara, "Pemampatan Citra Pas Foto dengan Menggunakan Algoritma Kompresi Joint-Photograpic Experts Group (JPEG) dan Principal Component Analysis (PCA)," Maj. Ilm. Teknol. Elektro, vol. 17, no. 1, 2018, doi: 10.24843/mite.2018.v17i01.p14.

[3] I. M. A. D. S. Atmaja, "KOMPRESI CITRA MEDIS MENGGUNAKAN PACKET WAVELET TRANSFORM DAN RUN LENGTH ENCODING,” Matrix J. Manaj. Teknol. dan Inform., vol. 8, no. 1, 2018, doi: 10.31940/matrix.v8i1.739.

[4] B. D. Raharja and P. Harsadi, "IMPLEMENTASI KOMPRESI CITRA DIGITAL DENGAN MENGATUR KUALITAS CITRA DIGITAL,” J. Ilm. SINUS, vol. 16, no. 2, 2018, doi: 10.30646/sinus.v16i2.363.

[5] "Aplikasi Kompresi Citra Dengan Matlab R2015a Menggunakan Metode Discrete Cosine Transform (DCT) dan Kuantisasi," J. Ilm. Komputasi, vol. 17, no. 1, 2018, doi: 10.32409/jikstik.17.1.2339.

[6] S. I. Murpratiwi and I. M. O. Widyantara, "Pemilihan Algoritma Kompresi Optimal untuk Citra Digital Bitmap," Maj. Ilm. Teknol. Elektro, vol. 17, no. 1, 2018, doi: 10.24843/MITE.2018.v17i01.P13.

[7] M. Aria and A. Sanjaya, "Teknik Kompresi pada Transmisi Data Citra Payload KOMURINDO," Komputika J. Sist. Komput., vol. 7, no. 2, 2018, doi: 10.34010/komputika.v7i2.1512.

[8] H. J. Park, K. B. Kim, and E. Y. Cha, "An effective color quantization method using color importance-based self-organizing maps," Neural Netw. World, vol. 25, no. 2, 2015, doi: 10.14311/NNW.2015.25.006.

[9] M. Narzillo, S. Abdurashid, N. Parakhat, and N. Nilufar, "Automatic speaker identification by voice based on vector quantization method," Int. J. Innov. Technol. Explor. Eng., vol. 8, no. 10, 2019, doi: 10.35940/ijitee.J9523.0881019.

[10] F. A. Sianturi, "Kompresi File Citra Digital Dengan Arithmetic Coding," J. Tek. Inform. Unika St. Thomas, vol. 03, no. 1, 2018. 